Original Research Paper

\title{
Pengembangan Wisata Air Muara Selayar sebagai Alternatif Destinasi Wisata Pada Masa New Normal Life untuk meningkatkan Perekonomian Masyarakat di Desa Pijot, Kecamatan Keruak
}

\author{
Embun Suryani $^{1 *}$, L.M. Furkan ${ }^{1}$, Zainal Abidin ${ }^{1}$, Sarifudin ${ }^{1}$, Siti Aisyah Hidayati ${ }^{1}$ \\ ${ }^{1}$ Fakultas Ekonomi dan Bisnis, Universitas Mataram, Mataram, Indonesia
}

https://doi.org/10.29303/jpmpi.v3i2.1114

Sitasi: Suryani, E., Furkan, L. M., Abidin, Z., Sarifudin \& Hidayati, S. A. (2021). Pengembangan Wisata Air Muara Selayar sebagai Alternatif Destinasi Wisata Pada Masa New Normal Life untuk meningkatkan Perekonomian Masyarakat di Desa Pijot, Kecamatan Keruak. Jurnal Pengabdian Magister Pendidikan IPA 4(4)

\author{
Article history \\ Received: 02 Oktober 2021 \\ Revised: 20 Oktober 2021 \\ Accepted: 07 November 2021 \\ *Corresponding Author: \\ Embun Suryani, Fakultas \\ Ekonomi dan Bisnis \\ Universitas Mataram, Mataram, \\ Indonesia \\ Email: \\ embunsuryani@unram.ac.id
}

Abstract: Desa Pijot memiliki potensi wisata bahari yang sangat penting, karena merupakan pintu gerbang terdekat untuk memasuki daerah-daerah wisata Pantai Pink dan 27 gili melalui wilayah perairan. Namun, kondisi pandemik covid19 menyebabkan industry pariwisata terdampak paling parah, karena diberlakukannya kebijakan pembatasan sosial skala besar, bahkan di beberapa Negara diberlakukan "lockdown". Hal ini menyebabkan penurunan drastis kunjungan wisatawan dari daerah lain dan wisatawan mancanega. Di sisin lain, masyarakat lokal tetap membutuhkan tempat untuk berekreasi dengan cara aman dan untuk menjadi agar kegiatan ekonomi di destinasi wisata tidak mati sama sekali. Dampak pandemik ini menyebabkan kegiatan ekonomi terdampak secara signifikan, yang jika tidak segera diatasi akan menyebabkan tingkat kemiskinan masyarakat akan bertambah parah. Untuk itu, melalui kegiatan ini akan dikembangkan atraksi wisata yang dapat dinikmati oleh masyarakat lokal dengan cara aman dan dengan harga terjangkau. Atraksi wisata yang berpotensi untuk dikembangkan di Desa Pijot adalah wisata air di Muara Selayar yang terletak di muara sungai pantai Pijot. Target yang ingin dicapai adalah terbentuknya atraksi wisata sepeda air, tempat bersantai, dan tempat berwisata kuliner dengan berbasis potensi local. Sepeda air akan dibuat dari bahan-bahan bekas, sedangkan spot photo, tempat bersantai, dan angkringan akan terbuat dari bahan lokal yaitu bambu. Pengelolaan tempat wisata air ini akan dikelola oleh Pokdarwis Desa Pijot yang akan menjadi bagian dari kegiatan bisnis BUMDes desa tersebut. Untuk mencapai target tersebut, digunakan pendekatan Participatory Rural Appraisal yang menekankan keterlibatan masyarakat dalam keseluruhan kegiatan mulai dari perencanaan, pelaksanaan dan evaluasi program. Kegiatan ini terbagi tiga yaitu: 1) sosialisasi tentang pembentukan dan pengelolaan destinasi dan atraksi wisata; 2) demonstration plot pembentukan atraksi wisata; dan 3) pendampingan pengelolaan destinasi Wisata Muara Selayar Desa Pijot. Kegiatan ini dilaksanakan bermitra dengan dua kelompok sasaran yaitu Pokdarwis dan pengelola BUMDes Desa Pijot. Hasil yang diperoleh dalam kegiatan ini adalah terbentuknya berbagai atraksi wisata di Muara Selayar Desa Pijot, seperti atraksi wisata rakit bamboo dan spot photo. Manfaat yang diperoleh Pokdarwis Desa Pijot selama kegiatan ini adalah terciptanya lapangan kerja bagi mereka untuk mengelola wisata air Muara Selayar. Keberadaan Wisata Muara Selayar diharapkan menjadi income generating bagi seluruh masyarakat Desa Pijot. Keberadaan spot photo, penyewaan rakit, retribusi parkir dan angkringan bisa menciptakan pendapatan bagi masyarakat.

Keywords: Desa Pijot; new normal; wisata air 


\section{Pendahuluan}

Wabah virus korona (COVID-19) telah membebani banyak kegiatan ekonomi di seluruh dunia. Guncangan terjadi secara tiba-tiba dan bersamaan di berbagai negara, dan ditandai dengan ketidakpastian yang signifikan mengenai besaran dan durasinya. Rekomendasi WHO untuk mengurangi penyebaran infeksi adalah melalui kebijakan jarak fisik dengan menjaga kontak fisik dengan orang lain, serta menghindari kegiatan berkumpul dalam satu tempat (WHO, 2020). Beberapa negara juga menerapkan kebijakan "lockdown" hingga batas waktu tertentu, dan beberapa bahkan tidak menetapkan batas waktu (BBC, 2020). Kebijakan pembatasan mobilitas dan kerumunan demi mengurangi penyebaran Covid-19 berdampak langsung pada sektor pariwisata. Sejak Covid-19 belum diumumkan sebagai pandemi global, pemerintah Indonesia telah mengeluarkan kebijakan untuk mengantisipasi kemungkinan penyebaran Covid-19 di Indonesia.

Akibat dari Pandemi covid-19 yang berlangsung selama beberapa bulan ini menyebabkan melemahnya aktivitas perekonomian. Aktivitas ekonomi meliputi kegiatan produksi, distribusi, dan konsumsi (Yuniarti et al., 2020). Berbagai aktivitas perekonomian mulai dari sektor pariwitasa hingga perdagangan terpaksa harus menutup usahanya dan mengurumahkan para karyawannya. Sejumlah hotel di daerah-daerah wisata seperti Bali, Jakarta, dan Yogyakarta Surabaya ditutup. Pemutusan hubungan kerja (PHK) menjadi langkah efektif bagi perusahaan untuk mengurangi kerugian perusahaan yang semakin bertambah (Syaharuddin, 2020).

Di sisi lain, Desa Pijot merupakan pintu gerbang terdekat untuk memasuki daerah-daerah wisata Pantai Pink dan 27 gili melalui wilayah perairan. Sebelum para wisatawan berangkat menuju pulau-pulau kecil, mereka akan membeli aneka keperluan di Desa Pijot dan Tanjung Luar. Tempat penyeberangan pun tersedia di Desa Pijot, Desa Tanjung Luar dan Desa Ketapang Raya. Desa Pijot Kecamatan Keruak merupakan sebuah desa yang terletak di bagian paling ujung timur dan di pinggir pantai Kabupaten Lombok Timur Pulau Lombok Provinsi NTB. Luas desa ini mencapai 715 Ha dengan penduduk berjumlah 8.257 orang $^{1}$. Secara administrasi, batas-batas desa ini meliputi ${ }^{2}$ : sebelah utara berbatasan dengan Desa Pijot Utara; sebelah timur berbatasan dengan Desa Mencah/Laut; sebelah selatan berbatasan dengan Desa Tanjung Luar/ Desa Ketapang Raya; dan sebelah barat berbatasan dengan Desa Ketangge Jeraeng/ Desa Montong Belae.

Pariwisata sebagai salah satu potensi yang dimiliki oleh Desa Pijot untuk meningkatkan kegiatan perekonomiannya akan menjadi terancam dengan terjadinya pandemik covid19 ini. Hai ini akan berimbas pada kesejahteraan masyarakat Desa Pijot, karena kondisi penduduk dilihat dari mata pencaharian dan kesejahteraannya masih tergolong memprihatinkan. Jumlah penduduk yang tidak bekerja cukup besar yaitu sekitar $15 \%$ dari jumlah penduduk yang tergolong angkatan kerja. Selain itu, penduduk Desa Pijot yang tergolong prasejahtera dan sejahtera 1 juga cukup tinggi yaitu sebesar 23\%, sedangkan sebagian besar keluarga (51\%) tergolong sebagai keluarga sejahtera 2 dan sisanya sebesar $26 \%$ tergolong keluarga sejahtera 3.

Sebelum pandemik ekonomi masyarakat Desa Pijot banyak berasal dari kegiatan pariwisata, namun sejak pandemik kegiatan ekonomi di sektor wisata menjadi menurun drastis. Untuk itu, potensi wisata yang dimiliki oleh Desa Pijot harus digeser ke bentuk wisata yang aman untuk dilakukan pada masa pandemik ini. Seperti yang nampak saat ini pengelolaan potensi wisata bahari Desa Pijot masih belum tertata baik, belum berkelanjutan, dan masih bersifat parsial. Informasi menyangkut daya tarik daerah tujuan wisata, alternatif rute yang dapat ditempuh, maupun biaya yang diperlukan belum tersedia.

Salah satu bentuk wisata yang aman adalah wisata alam, untuk itu dengan adanya hulu sungai yang cukup besar dan dengan intensitas yang selalu memadai di Desa Pijot, maka sangat besar potensi untuk mengembangkan atraksi wisata di lokasi ini. Namun, masyarakat lokal Desa Pijot belum mampu mengembangkan dan mengelola destinasi wisata tersebut. Hal ini disebabkan karena rendahnya kemampuan, ketrampilan dan kualitas sumber daya manusianya. Pengembangan sentra wisata bahari tidak bisa dilepaskan dari masyarakat di sekitar kawasan wisata, karena masyarakat lokal berperan besar dalam keberhasilan sebuah pengembangan destinasi wisata. Pengembangan kawasan wisata dapat dilaksanakan berdasarkan interaksi subsistem yang ada (Che et al. 2005; Aref \& Gill 2009), produk unggulan sebagai ciri khas penguat kawasan wisata (Kuswiati 2008) dan lingkungan di 
sekelilingnya (Hakim \& Nakagoshi, 2009; Desbiolles 2010). Selanjutnya, menurut Laverack dan Thangphet (2009), keterlibatan masyarakat dan pemberdayaannya juga merupakan salah satu cara untuk meningkatkan kemampuan rakyat yang selama ini dinilai relative lemah, serta sekaligus akan membantu pemerintah dalam memerangi terjadinya urban sprawl yang selama ini belum ada cara ampuh untuk memeranginya.

Lebih lanjut, untuk mengembangkan destinasi wisata air Muara Selayar Desa Pijot maka segala kegiatan ekonomis terkait destinasi wisata harus dikelola secara professional dengan membentuk suatu wadah untuk mengelola potensi spesifik desa. Badan Usaha Milik Desa (BUMDes) merupakan salah satu wadah yang dapat digunakan untuk mencapai target di atas. BUMDes adalah badan usaha yang seluruh atau sebagian besar modalnya dimiliki oleh desa melalui penyertaan langsung yang berasal dari kekayaan desa yang dipisahkan guna mengelola aset, jasa pelayanan, dan usaha lain untuk sebesar-besarnya kesejahteraan masyarakat desa. Pengelolaan BUMDes sepenuhnya dilaksanakan oleh masyarakat desa, yaitu dari desa, oleh desa, dan untuk desa (Zulkarnaen, 2016). Tujuan awal pendirian Bumdes adalah untuk menghimpun kegiatan-kegiatan ekonomi masyarakat berbasis potensi asli desa ke dalam sebuah badan usaha yang dikelola secara professional. Karena itu, melalui pengembangan dan penguatan Bumdes, potensi desa bisa dioptimalkan untuk menuju desa wirausaha yang mampu menggerakkan perekonomian dan menyediakan lapangan kerja bagi seluruh lapisan masyarakat.

Untuk itu, melalui kegiatan ini akan dilakukan pengembangan dan pengelolaan partisipatif destinasi wisata air muara selayar berbasis "Sustainable Tourism Observatory (STO)" sebagai bentuk pendekatan holistik dan berkelanjutan berbasis hasil-hasil riset multidisiplin. Pengelolaan sentra agroekowisata berbasis STO ini akan mengutamakan partisipasi masyarakat lokal, optimalisasi keuntungan untuk masayarakat setempat dan pengunjung, reduksi pengaruh negatif terhadap masyarakat maupun lingkungan. Diharapkan desa ini menjadi model science-technopark Universitas Mataram di bidang pengelolaan destinasi wisata air berkelanjutan. Kegiatan ini diharapkan akan mampu meningkatkan ketrampilan dan keberdayaan masyarakat, sehingga sejalan dengan program pemerintah desa yang cukup menekankan pada kegiatan pembinaan dan pemberdayaan masyarakat, yang ditunjukkan oleh 25\% dana APBDes dialokasi untuk kedua kegiatan tersebut.

Untuk itu, perlu dilakukan kegiatan pengabdian masyarakat untuk mensosialisasikan dan melatih masyarakat Desa Pijot dalam pengembangan destinasi Wisata air Muara Selayar Desa Pijot. Kegiatan yang akan dilakukan adalah iventarisasi potensi local yang dimiliki (fisik alami, fisik buatan, non-fisik) dalam rangka mengembangkan destinasi wisata Muara Selayar, FGD (Focus Group Discussion) terkait desain pengembangan wisata air Muara Selayar, , penguatan kapasitas kelembagaan lokal, penyuluhan kepada masyarakat terkait STO, dan kegiatan demonstration plot (demplot) untuk peningkatan ketrampilan/kapasitas masyarakat dan kelompok sasaran umumnya dalam mengembangkan destinasi Wisata air Muara Selayar Desa Pijot.

Adapun tujuan dari kegiatan ini adalah untuk mengembangkan manajemen pengelolaan destinasi wisata yang berkelanjutan sebagai upaya untuk memberdayakan masyarakat berbasis ekonomi kreatif. Wisata tersebut merupakan wisata yang dapat dinikmati oleh masyarakat lokal dengan cara aman pada masa "new normal" dan dengan harga terjangkau. Atraksi wisata yang berpotensi untuk dikembangkan di Desa Pijot adalah wisata air di Muara Selayar yang terletak di muara sungai pantai Pijot. Target yang ingin dicapai adalah terbentuknya atraksi wisata sepeda air, tempat bersantai, dan tempat berwisata kuliner dengan berbasis potensi local. Sepeda air akan dibuat dari bahan-bahan bekas, sedangkan spot photo, tempat bersantai, dan angkringan akan terbuat dari bahan lokal yaitu bambu. Pengelolaan tempat wisata air ini akan dikelola oleh Pokdarwis Desa Pijot yang akan menjadi bagian dari kegiatan bisnis BUMDes desa tersebut. Selanjutnya, kegiatan ini dilaksanakan bermitra dengan Pokdarwis Desa Pijot dan BUMDes Desa Pijot.

\section{Permasalahan Mitra}

Berdasarkan survey awal dan diskusi dengan Mitra dan tiga kelompok sasaran maka permasalahan prioritas yang akan ditangani, yaitu:

- Aspek manajemen pengelolan: berdasarkan aspek ini sebagian besar kelompok sasaran 
belum memiliki pemahaman dan pengetahuan terkait manajemen pengelolaan destinasi dan atraksi wisata secara berkelanjutan, khususnya pada era "new normal". Selain itu, Pengelolaan potensi wisata yang dimiliki desa tersebut masih belum tertata baik, belum berkelanjutan, dan masih bersifat parsial.

- Aspek produksi: berdasarkan aspek ini kelompok sasaran masih memiliki kemampuan yang sangat terbatas untuk: 1) mengembangkan 1) bagaimana mengembangkan kawasan wisata ar Muara Selayar Desa Pijot; 2) bagaimana mengelola lingkungan di Desa Pijot agar menjadi bersih, indah, serasi dan unik untuk menarik wisatawan; dan 3) bagaimana meningkatkan kesadaran masyarakat akan dampak negatif wisata, seperti sampah, abrasi pantai, persaingan usaha masyarakat setempat, sampai degradasi moral maupun kearifan lokal.

- Aspek pemasaran: berdasarkan aspek ini masyarakat desa Pijot memiliki keterbatasan kemampuan bagaimana mempromosikan Wisata Air Muara Selayar Desa Pijot secara efektif dan menciptakan brand Wisata Air Muara Selayar Desa Pijot yang unik dan berbasis muatan lokal. Hal ini ditunjukkan oleh rendahnya kemampuan kelompok sasaran untuk menerapkan berbagai sistem pemasaran terutama yang berbasis cyber marketing. Dengan metode pemasaran ini diharapkan akan memperluas konsumen sasaran.

- Aspek keuangan-permodalan: berdasarkan aspek ini, kelompok sasaran mengalami permasalahan untuk mengakses modal guna mengembangkan usahanya agar mampu memproduksi produk yang layak jual, mulai dari bentuk hingga kemasan. Kelompok sasaran juga memiliki kemampuan terbatas mengelola keuangan usahanya tersebut. Dilain sisi, BUMDes sebagai badan usaha milik desa belum mampu berperan sebagai wadah untuk mengakomodir kegiatankegiatan ekonomis masyarakat Desa Pijot umumnya dan kelompok sasaran pada khususnya.

- Aspek ekonomi: Desa Pijot memiliki tingkat pengangguran usia produktif yang cukup tinggi yang disebabkan karena keterbatasan kualitas sumber daya manusianya. Selanjutnya kondisi ini menyebabkan rendahnya tingkat pendapatan dan daya beli masyarakat. Melalui kegiatan ini diharapkan, masyarakat akan lebih berdaya melalui penciptaan ekonomi kreatif yang berbasis wisata, sehingga masyarakat mampu menciptakan sumber pendapatan baru agar dapat meningkatkan kesejahteraannya.

\section{Solusi Dan Target Luaran}

Desa Pijot memiliki potensi wisata yang sangat menjanjika, dimana Desa Pijot merupakan pintu gerbang terdekat untuk memasuki daerahdaerah wisata Pantai Pink dan 27 gili melalui wilayah perairan. Sebelum para wisatawan berangkat menuju pulau-pulau kecil, mereka akan membeli aneka keperluan di Desa Pijot dan Tanjung Luar. Tempat penyeberangan pun tersedia di Desa Pijot, Desa Tanjung Luar dan Desa Ketapang Raya. Namun demikian, kondisi penduduk dilihat dari mata pencaharian dan kesejahteraannya masih tergolong memprihatinkan. Jumlah penduduk yang tidak bekerja cukup besar yaitu sekitar $15 \%$ dari jumlah penduduk yang tergolong angkatan kerja. Selain itu, jumlah penduduk Desa Pijot yang tergolong prasejahtera dan sejahtera 1 juga cukup tinggi yaitu sebesar $23 \%$. Kondisi ini sangat ironis, dengan potensi wisata bahari yang begitu besar namun tidak dapat dinikmati secara optimal oleh seluruh masyarakat. Untuk itu perlu diciptakan suatu kegiatan ekonomi kreatif yang mampu meningkatkan keberdayaan masyarakat Desa Pijot agar terlepas dari keterpurukan ekonomi.

Pengelolaan wisata partisipatif berbasis "Sustainable Tourism Observatory (STO)" merupakan bentuk pendekatan holistik dan berkelanjutan berbasis hasil-hasil riset multidisiplin. Model pengelolaan pariwisata ini dapat memberikan kontribusi nyata untuk meningkatkan kesejahteraan masyarakat. Lebih lanjut dijelaskan bahwa pengelolaan pariwisata dengn model tersebut mengutamakan pelibatan masyarakat setempat untuk menjadi pelaku yang terlibat langsung di wilayah yang menjadi destinasi wisata. Melalui pengelolaan wisata berbasis STO ini memerlukan beberapa langkah dan tahapan yang melibatkan "indigenous people". Adapun rincian solusi permasalahan yang ditawarkan adalah: 1) meningkatkan kapasitas kawasan wisata dengan menyediakan fasilitas umum bagi wisatawan; 2) meningkatkan kapasitas kawasan wisata dengan 
mengembangkan atraksi wisata dengan melibatkan seluruh elemen masyarakat; 3) mengajak dan mendorong masyarakat untuk berkreatifitas mengelola Wisata Air Muara Selayar Desa Pijot agar menjadi asri dan indah; dan 4) mensosialisasikan pemilahan limbah rumah tangga dan terutama limbah destinasi Wisata Air Muara Selayar agar lingkungan menjadi besih dan asri untuk mendukung pengembangan destinasi wisata tersebut.
Kelompok sasaran yang akan dituju pada kegiatan ini memiliki peran penting dalam pengembangan ekonomi kreatif Desa Pijot. Kegiatan ini akan diawali dengan kegiatan sosialisasi tentang bagaimana manajemen pengelolaan destinasi wisata. Kemudian dilanjutkan dengan aplikasi pola pelatihan dan pembelajaran, Demonstration Plot (Demplot), dan pendampingan. Cakupan dan sasarannya nampak seperti pada Tabel 1 berikut:

Tabel 1. Permasalahan dan Rencana Kerja

\begin{tabular}{|c|c|c|}
\hline No. & Bidang dan Permasalahan & Solusi yang ditawarkan/ Rencana Kerja \\
\hline 1 & $\begin{array}{l}\text { Produksi } \\
\text { - Manajemen pengelolaan destinasi wisata air } \\
\text { Muara Selayar } \\
\text { - Ketersediaan atraksi dan layanan dalam } \\
\text { destinasi wisata air. }\end{array}$ & $\begin{array}{l}\text { - Meningkatkan pengetahuan dan pemahaman } \\
\text { kelompok sasaran untuk mengelola destinasi wisata } \\
\text { yang berkelanjutan dan menerapkan protocol covid19 } \\
\text { dengan ketat } \\
\text { - Memberikan pelatihan dan demplot pembuatan } \\
\text { atraksi-atraksi wisata berbasis bahan lokal }\end{array}$ \\
\hline 2. & $\begin{array}{l}\text { Pemasaran } \\
\text { Rendahnya kemampuan kelompok sasaran untuk } \\
\text { menerapkan berbagai sistem pemasaran } \\
\text { terutama yang berbasis cyber marketing. } \\
\text { Akibatnya kelompok sasaran tidak akan mampu } \\
\text { memperluas konsumen sasaran untuk } \\
\text { produknya. }\end{array}$ & $\begin{array}{l}\text { Merancang metode pemasaran yang berbasis online } \\
\text { salah satunya dengan memanfaatkan sosial media dan } \\
\text { mendesign vlog bagi destinasi Wisata Air Muara } \\
\text { Selayar Desa Pijot. Dengan metode pemasaran ini } \\
\text { diharapkan produk-produk yang dihasilkan oleh } \\
\text { kelompok sasaran dapat disosialisasikan secara lebih } \\
\text { efektif dengan berbasis inovasi dan IT. }\end{array}$ \\
\hline 3. & $\begin{array}{l}\text { Manajemen keuangan-permodalan } \\
\text { - Bagaimana mendukung pelaksanaan dan } \\
\text { kelancaran usaha mandiri masyarakat Desa } \\
\text { Pijot dari sisi penyiapan permodalan dan } \\
\text { pengelolaan keuangan usaha. } \\
\text { - Bagaimana meningkatkan kapasitas BUMDes } \\
\text { dalam mengelola kegiatan-kegiatan ekonomis } \\
\text { masyarakat melalui aplikasi sistem informasi } \\
\text { akuntansi }\end{array}$ & $\begin{array}{l}\text { - Mendampingi kelompok sasaran dan masyarakat } \\
\text { dalam menjalankan usaha mandirinya dengan } \\
\text { manajemen yang professional } \\
\text { - Melatih, membina, dan mendampingi pengurus- } \\
\text { pengurus BUMDes dalam mengelola BUMDes } \\
\text { sebagai badan usaha milik desa yang mewadahi } \\
\text { kegiatan-kegiatan ekonomis masyarakat. }\end{array}$ \\
\hline 4. & $\begin{array}{l}\text { Ekonomi } \\
\text { - Mengurangi tingkat pengangguran } \\
\text { - Meningkatkan pendapatan dan daya beli } \\
\text { masyarakat agar dapat meningkatkan } \\
\text { kesejahteraan mereka }\end{array}$ & $\begin{array}{l}\text { - Melibatkan seluruh lapisan masyarakat Desa Pijot } \\
\text { dalam mengembangkan dan mengelola destinasi } \\
\text { Wisata Air Muara Selayar secara berkelanjutan }\end{array}$ \\
\hline
\end{tabular}

\section{Target dan Luaran}

Target dan luaran serta indikator capaian yang diharapkan dari program PPM (Program
Pengabdian Masyarakat) ini disajikan pada Tabel 2 berikut ini. 
Tabel 2. Rencana Target dan Luaran

\begin{tabular}{|c|c|c|}
\hline No & Jenis Luaran & Indikator Capaian \\
\hline \multicolumn{3}{|c|}{ Kegiatan pada aspek produksi } \\
\hline 1 & $\begin{array}{l}\text { - Pelatihan pengetahuan dan keterampilan } \\
\text { pengelolaan destinasi Wisata Air Muara } \\
\text { Selayar }\end{array}$ & $\begin{array}{l}\text { - Terbentuknya aneka atraksi yang berbasis } \\
\text { potensi lokal } \\
\text { - Meningkatnya pengetahuan dan kesadaran } \\
\text { kelompok sasaran untuk mengelola destinasi } \\
\text { wisata yang dimiliki secara berkelanjutan dan } \\
\text { comprehensive dengan selalu berorientasi } \\
\text { menjadi lingkungan yang bersih, sehat dan asri. } \\
\text { - Pendapatan kelompok sasaran program menjadi } \\
\text { meningkat }\end{array}$ \\
\hline \multicolumn{3}{|c|}{ Kegiatan pada aspek manajemen usaha } \\
\hline 1 & Pelatihan tentang pengelolaan keuangan & $\begin{array}{l}\text { Kelompok sasaran dapat melakukan pencatatan } \\
\text { dan pengelolaan pendapatan maupun pengeluaran } \\
\text { dari usaha yang dilakukan }\end{array}$ \\
\hline 2 & Pelatihan manajemen pemasaran & $\begin{array}{l}\text { Kelompok sasaran mampu memasarkan, } \\
\text { memperluas konsumen dan meningkatkan volume } \\
\text { penjualan produk yang dihasilkan. }\end{array}$ \\
\hline
\end{tabular}

\section{Metode}

Berdasarkan solusi atas permasalahan prioritas desa dan untuk mewujudkan ekonomi kreatif melalui pengembangan dan pengelolaan destinasi Wisata Air Muara Selayar di Desa Pijot, maka kegiatan ini akan dilakukan melalui pendekatan Participatory Rural Appraisal (PRA) dan Community development. Kedua pendekatan ini menekankan keterlibatan masyarakat secara langsung sebagai subyek dan obyek dalam pelaksanaan keseluruhan kegiatan mulai dari perencanaan, pelaksanaan dan evaluasi kegiatan.

Sedangkan metode yang digunakan untuk melaksanakan kegiatan ini adalah Kaji Tindak Partisipatif melalui pelatihan, pembelajaran, Demonstration plot (Demplot), dan pendampingan secara berkelanjutan dan berkolaborasi dengan kelompok sasaran.

\section{Teknis Pelaksanaan Kegiatan}

Teknis pelaksanaan kegiatan PPM di Desa Pijot adalah sebagai berikut:

\section{Persiapan.}

Pada tahap persiapan ini dilakukan untuk menginventarisasi adanya perubahan kondisi masyarakat terkait pengetahuan, pemahaman, keterlibatan, dan ketrampilan yang dimiliki masyarakat dalam mengembangkan ekonomi kreatif di Desa Pijot. Selanjutnya, juga dilakukan inventarisasi kapabilitas dari kelompok sasaran binaan yang akan menjadi ujung tombak pengembangan destinasi Wisata Air Muara Selayar sehingga desain kegiatan

yang telah dilakukan dapat memberikan solusi bagi permasalahan mitra. Selain itu di tahap awal ini juga akan dilakukan sosialisasi program secara lebih luas.

2. Pelaksanaan kegiatan.

Pelaksanaan kegiatan meliputi kegiatan penguatan kelompok melalui kegiatan workshop, demplot dan pendampingan pengembangan dan pengelolaan destinasi dan atraksi Wisata Air Muara Selayar. Demplot akan dilakukan pada tahap proses pembuatan atraksi dan layanan lainnya hingga destinasi wisata bisa dibuka. Dari kegiatan ini diharapkan kelompok sasaran dapat memulai dan mengembangkan destinasi Wisata Air Muara Selayar tersebut.

3. Evaluasi dan monitoring kegiatan.

Evaluasi dan monitoring kegiatan dilakukan secara periodik dengan melibatkan anggota pelaksana. Evaluasi ini dilaksanakan untuk mengetahui derajat keberhasilan kegiatan berdasarkan target yang telah ditetapkan. Hasil evaluasi kegiatan akan dijadikan dasar untuk membuat kebijakan dan program pengembangan pada tahap berikutnya. Tabel 3 
berikut menggambarkan secara terperinci uraian kegiatan PPM Kemitraan di Desa Pijot.

Tabel 3. Uraian Kegiatan Program Pengabdian pada Masyarakat Kemitraan di Desa Pijot

\begin{tabular}{|c|c|c|c|}
\hline No. & Uraian & Metode & $\begin{array}{c}\text { Peran Pemerintah } \\
\text { Desa }\end{array}$ \\
\hline 1 & $\begin{array}{l}\text { Produksi } \\
\text { - Meningkatkan kapasitas masyarakat desa } \\
\text { umumnya dan kelompok sasaran khususnya } \\
\text { dengan mengembangkan berbagai kegiatan } \\
\text { ekonomi kreatif. } \\
\text { - Melatih, melakukan demplot dan pendampingan } \\
\text { pengelolaan destinasi wisata dan pembuatan } \\
\text { atraksi wisata serta layanan lainnya. Selain itu } \\
\text { juga diberikan pelatihan manajemen } \\
\text { pengelolaan destinasi wisata tersebut, misalnya } \\
\text { terkait pengelolaan yang efisien, menghitung } \\
\text { biaya, menghitung laba, dan lain sebagainya }\end{array}$ & $\begin{array}{l}\text { - Focus group discussion } \\
\text { (FGD) dengan seluruh } \\
\text { kelompok masyarakat } \\
\text { dan aparat desa } \\
\text { - Pelatihan dan } \\
\text { pembelajaran } \\
\text { menggunakan } \\
\text { pendekatan andragogis } \\
\text { (pembelajaran orang } \\
\text { dewasa) melalui demplot }\end{array}$ & $\begin{array}{l}\text { Dukungan tempat dan } \\
\text { sarana untuk melakukan } \\
\text { penyuluhan dan FGD } \\
\text { - Menggerakkan untuk } \\
\text { ikut berpartisipasi dan } \\
\text { menyediakan sarana } \\
\text { untuk melakukan } \\
\text { demplot }\end{array}$ \\
\hline 2. & $\begin{array}{l}\text { Pemasaran } \\
\text { - Merancang dan mendesign vlog bagi produk- } \\
\text { produk ekonomi kreatif dari masyarakat Desa } \\
\text { Pijot } \\
\text { - Merancang dan mendesign brand bagi destinasi } \\
\text { Wisata Air Muara Selayar di Desa Pijot }\end{array}$ & $\begin{array}{l}\text { Pelatihan dan workshop } \\
\text { pembuatan website dan } \\
\text { mendesign brand }\end{array}$ & $\begin{array}{l}\text { - Dukungan tempat dan } \\
\text { sarana untuk melakukan } \\
\text { penyuluhan dan FGD }\end{array}$ \\
\hline 3. & $\begin{array}{l}\text { Manajemen (keuangan-permodalan) } \\
\text { - Mendampingi dan melakukan demplot cara } \\
\text { menjalankan usaha dengan manajemen yang } \\
\text { professional } \\
\text { - Membina dan mendampingi pengelolaan } \\
\text { BUMDes secara professional } \\
\text { - Membina dan mendampingi dalam } \\
\text { pengelolaan modal kerja }\end{array}$ & $\begin{array}{l}\text { - Demplot dan } \\
\text { pendampingan }\end{array}$ & $\begin{array}{l}\text { - Memfasilitasi kemitraan } \\
\text { usaha masyarakat } \\
\text { khususnya dengan } \\
\text { BUMDes dan LKM } \\
\text { - Memfasilitasi kemitraan } \\
\text { BUMDes khususnya } \\
\text { dengan investor dan } \\
\text { perbankan }\end{array}$ \\
\hline 5. & $\begin{array}{l}\text { Ekonomi } \\
\text { - Seluruh elemen secara kontinyu } \\
\text { mengembangkan produk-produk ekonomi } \\
\text { kreatif yang menunjang pengembangan } \\
\text { destinasi Wisata Air Muara Selayar di Desa } \\
\text { Pijot }\end{array}$ & $\begin{array}{l}\text { - Demplot dan } \\
\text { pendampingan }\end{array}$ & $\begin{array}{l}\text { - Menyiapkan tempat bagi } \\
\text { masyarakat untuk memulai } \\
\text { usahanya (tempat jualan di } \\
\text { destinasi wisata) }\end{array}$ \\
\hline
\end{tabular}

\section{Hasil dan Pembahasan}

\section{Pengembangan Atraksi Spot Photo di Wisata Muara Selayar Desa Pijot}

Atraksi spot photo menjadi salah satu atraksi yang banyak menarik minat pengunjung terutama anak muda millenial. Pembuatan spot photo bertujuan untuk berswafoto dan memperindah kawasan Wisata Muara Selayar. Umumnya

destinasi wisata berusaha menyajikan spot photo semenarik dan seunik mungkin. Seringkali spot photo inilah yang mendorong anak-anak muda millenial untuk berkunjung ke suatu lokasi wisata. Untuk itu, pada kegiatan ini dilakukan 
pendampingan terhadap Pokdarwis Desa Pijot photo, seperti nampak pada Gambar 1, 2, dan 3 untuk mendesign dan membentuk berbagai spot berikut.

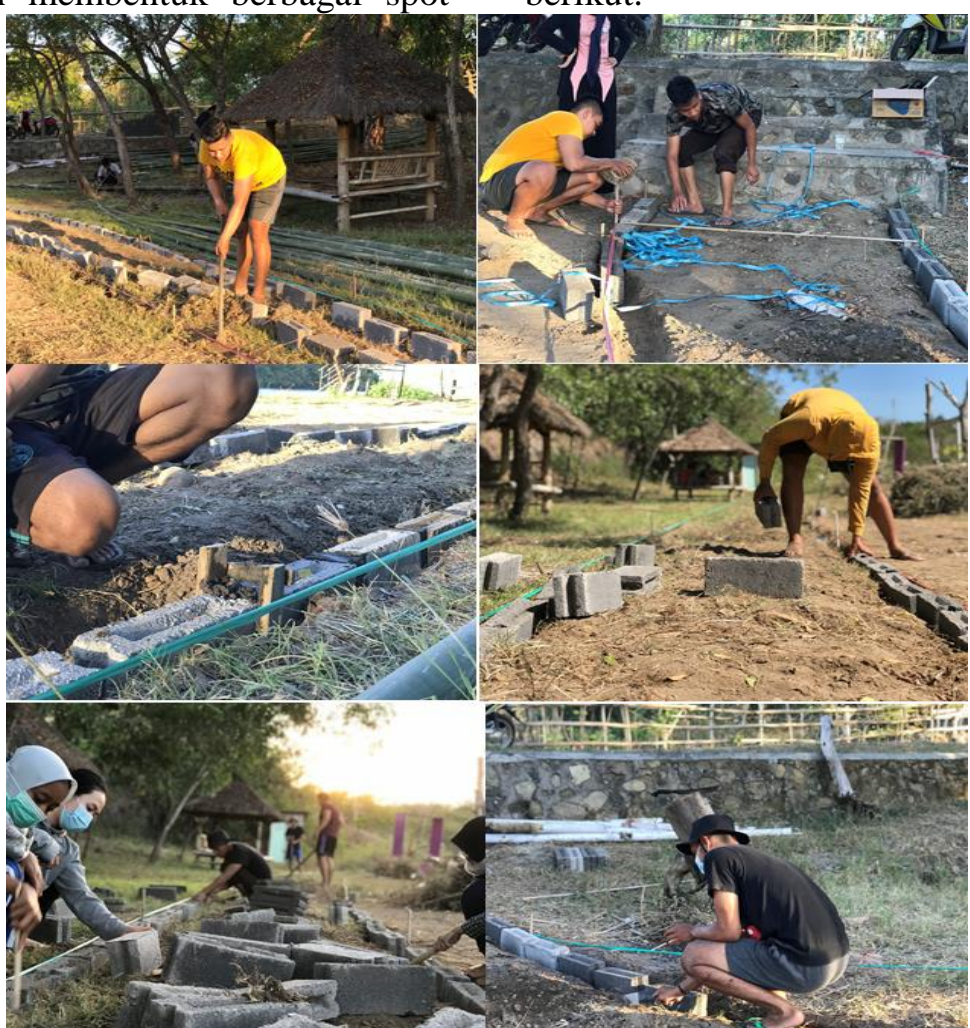

Gambar 1. Pembuatan jalan setapak untuk spot photo

Jalan setapak merupakan suatu proses pembuatan jalan di area sekitar Wisata Muara Selayar. Tujuan dari kegiatan ini yakni untuk menunjang penataan lokasi wisata dan penempatan spot foto agar tertata dengan rapi. Pembuatan jalan setapak ini memakan waktu 10 hari dimulai dari tanggal 28 Juni sampai tanggal 7 Juli 2021.

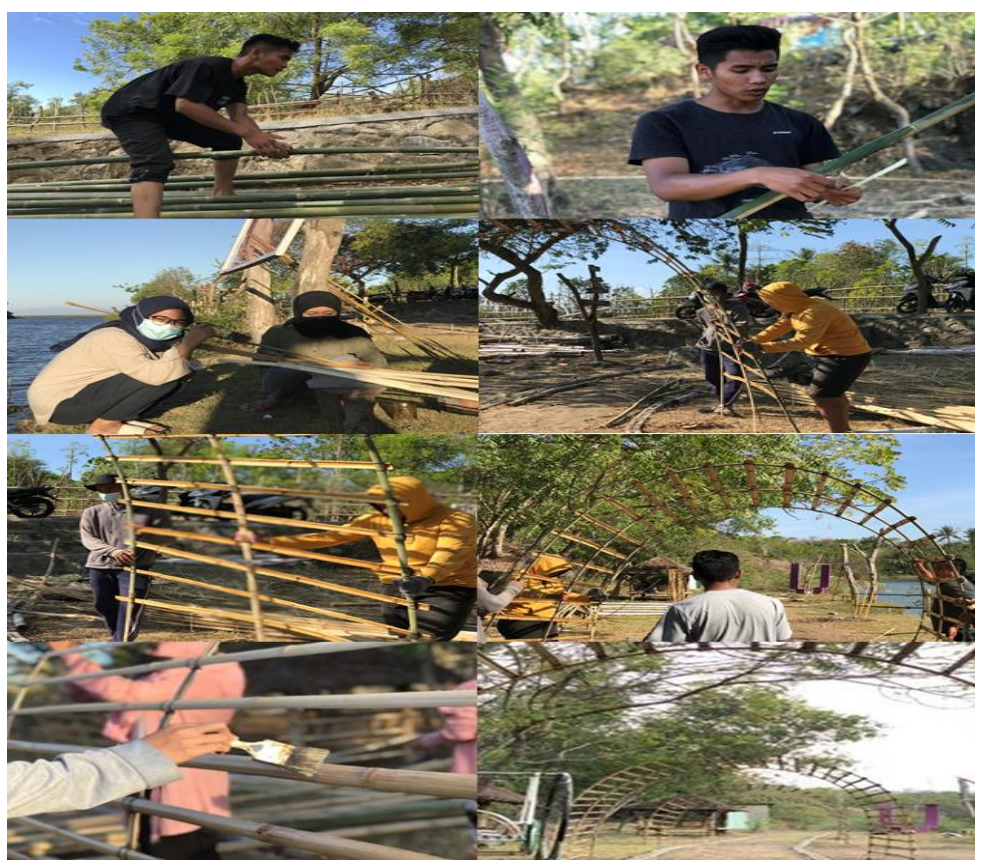


Gambar 2. Proses pembuatan lorong bambu untuk spot photo

Penataan spot foto yang bertujuan untuk menambah pesona keindahan pada wisata rakit tersebut dan dapat dijadikan sebagai daya tarik wisatawan. Daya tarik wisata adalah segala sesuatu yang memiliki keunikan, keindahan, serta hal- hal yang tidak dijumpai di tempat lain yang dapat dijadikan sebagai daya tarik wisatawan.

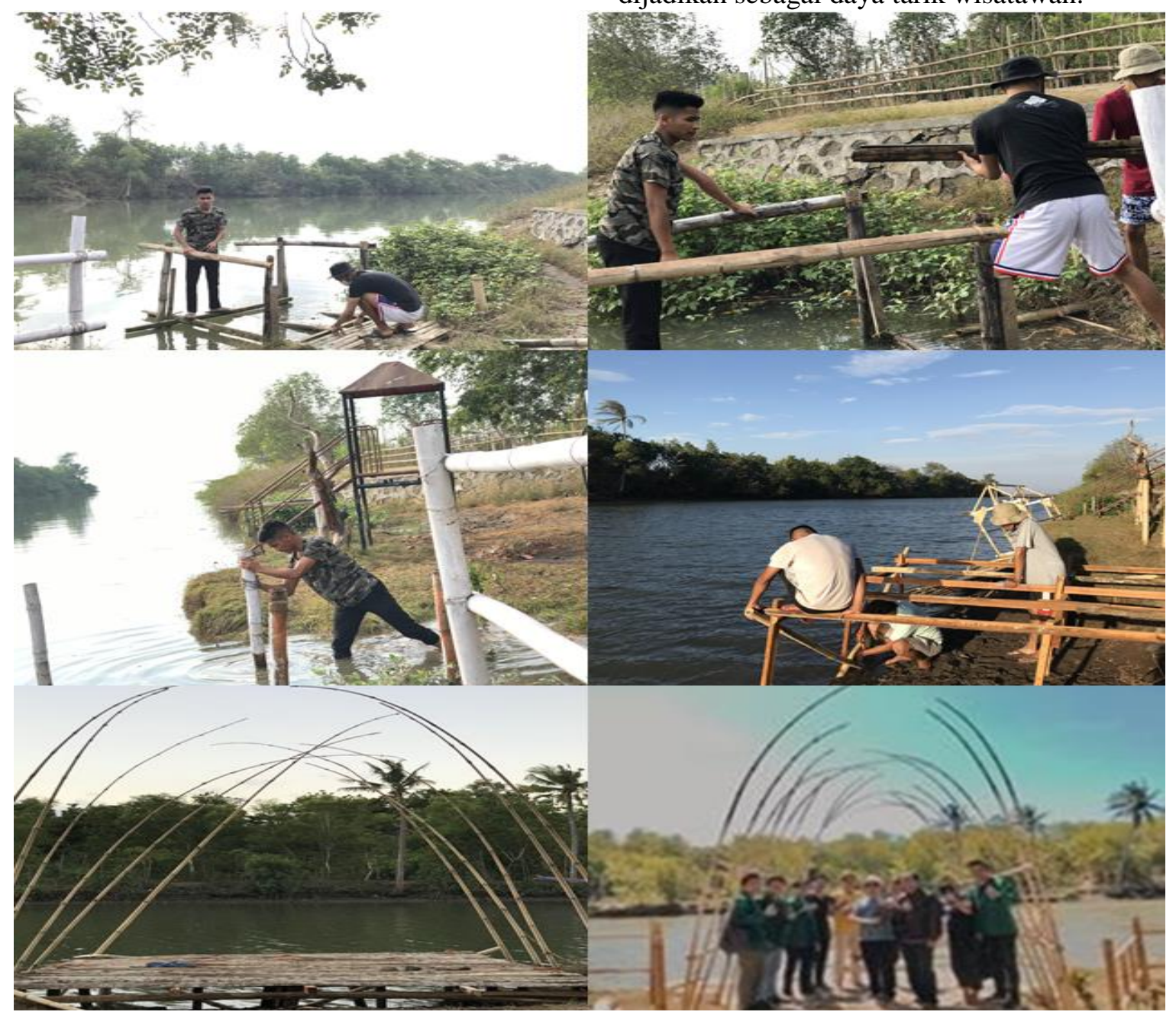

Gambar 3. Proses pembuatan dermaga untuk spot photo

Rakit bambu merupakan atraksi utama di

Keberadaan spot photo ini sangat penting bagi suatu lokasi wisata, selain sebagai atraksi wisata, juga akan memperindah lingkungan wisata. Spot photo yang dibuat pada kegiatan ini berbasis bahan lokal yaitu bambu, yang merupakan salah satu potensi perkebunan Desa Pijot. Dengan demikian, diharapkan kegiatan ini akan lebih menggerakkan roda perekonomian masyarakat Desa Pijot, bukan hanya pelaku wisata, tapi juga UKM lainnya.

\section{Pengembangan Atraksi Rakit Bambu di Wisata Muara Selayar Desa Pijot}

Wisata Muara Selayar yang menawarkan kepada

wisatawan sensasi mengelilingi Muara Selayar yang memiliki pemandangan yang sangat menarik dengan menggunakan rakit bambu. Seperti halnya tahun sebelumnya, tahun ini juga dibuat rakit bambu yang lebih menarik dengan memasukkan spot photo di atas rakit bambu, sehingga masyarakat akan semakin tertarik untuk menikmati pemandangan Muara Selayar sambil berswaphoto di atas rakit. Penggunaan rakit bambu ini dimaksudkan untuk memasukkan muata lokal yang dimiliki Desa Pijot, karena tanaman bambu 
merupakan salah satu potensi perkebunan yang dimiliki Desa Pijot. Bahan baku bambu juga dibuktikan memiliki daya tahan yang lebih lama di daerah perairan yang memiliki kadar garam cukup tinggi. Rakit bambu dibentuk sedemikian rupa dengan sentuhan kreatifitas tanpa menghilangkan kesan otentik dari bambu tersebut. Pembuatan rakit dari bambu memiliki nilai estitika yang lebih

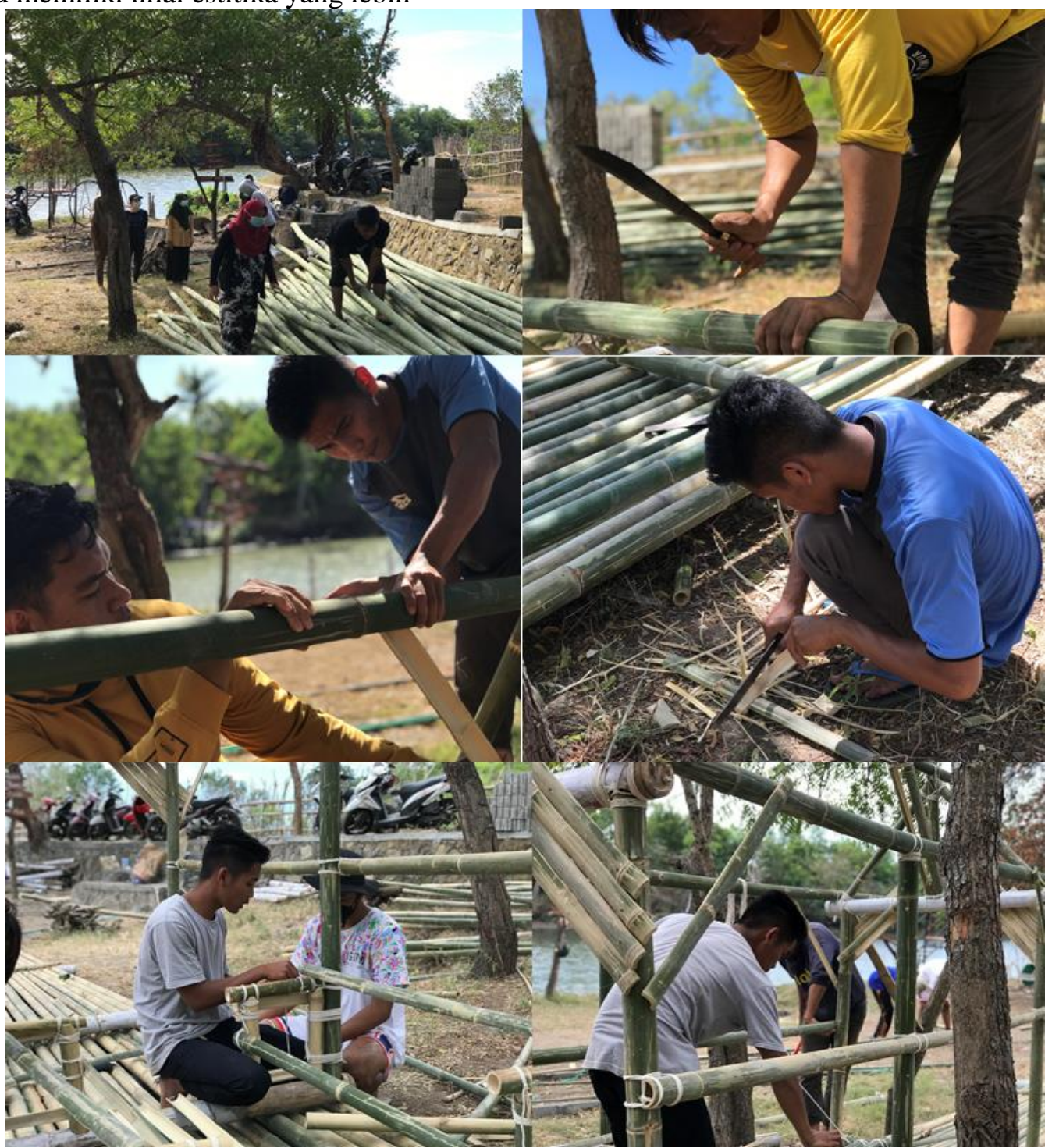

Gambar 4. Proses pembuatan rakit bambu

Pembuatan rakit bambu membutuhkan ketelitian yang tinggi, agar rakit bambu bisa seimbang, dan aman untuk digunakan oleh pengunjung. Untuk itu, dalam proses pembuatan ini menarik bagi wisatawan. Gambar 4 berikut ini menunjukkan proses pembuatan rakit bamboo bersama pokdarwis Desa Pijot dan KKN tematik Unram 2021. 


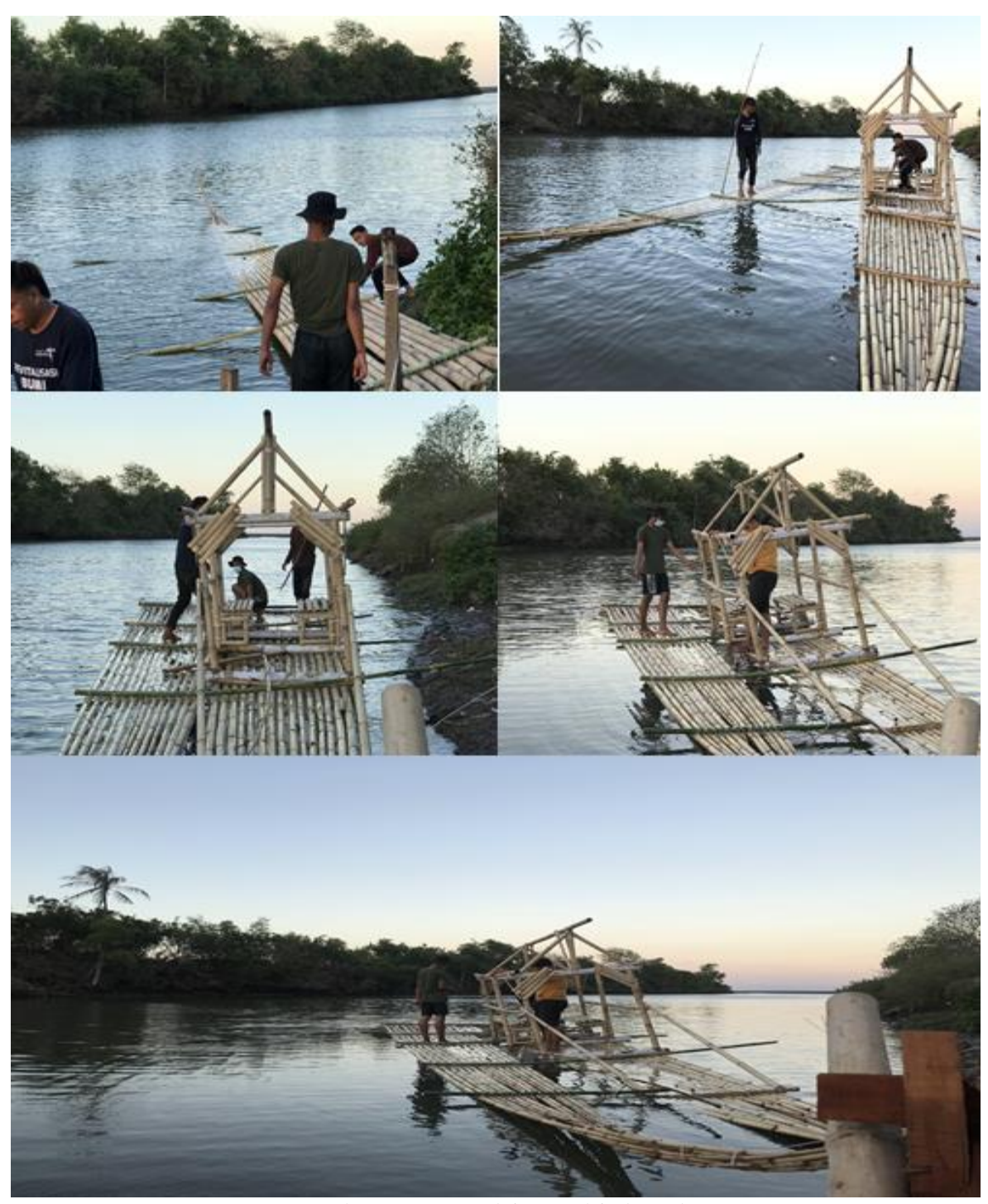

Gambar 5. Test drive rakit bambu

Pengembangan suatu destinasi wisata membutuhkan sarana untuk memperkenalkan lokasi tersebut sehingga mudah untuk diketahui dan dicapai oleh wisatawan. Salah satunya adalah dengan penunjuk jalan menuju lokasi wisata tersebut. Untuk itu, melalui kegiatan ini dibentuk papan penunjuk jalan disertai dngan gerbang selamat datang ke lokasi wisata bahari Desa Pijot.

\section{Dampak Ekonomi Kegiatan terhadap Kelompok Mitra}

Kegiatan pengembangan destinasi wisata air Muara Selayar Desa Pijot bertujuan untuk meningkatkan perekenomian masyarakat terutama kelompok sasaran. Pokdarwis sebagai salah satu mitra desa diharapkan akan merasakan dampak yang paling besar, selain tentu saja untuk seluruh kelompok masyarakat di Desa Pijot. Manfaat yang diperoleh Pokdarwis Desa Pijot selama kegiatan ini adalah terciptanya lapangan kerja bagi mereka untuk mengelola wisata air Muara Selayar. Keberadaan Wisata Muara Selayar diharapkan menjadi income generating bagi seluruh masyarakat Desa Pijot. Keberadaan spot photo, penyewaan rakit, retribusi parkir dan angkringan bisa menciptakan pendapatan bagi masyarakat.

\section{Kontribui Mitra terhadap pelaksanaan}

Kontribusi mitra sasaran terhadap pelaksanaan ini adalah berupa peran serta dalam setiap kegiatan yang dilakukan, hal ini terlihat dari antusiasme mitra untuk hadir dan ikut dalam 
melaksanakan setiap kegiatan. Kontribusi mitra juga terlihat dari kesediaan mereka menerima pelaksana pengabdian dengan memberikan sambutan yang ramah dan kesediaan mereka dalam menyediakan lokasi dan ikut berkontribusi untuk menyiapkan bahan baku yang dibutuhkan dalam setiap pelaksanaan kegiatan.

\section{Kesimpulan}

Kegiatan pengabdian kemitraan ini dilaksanakan dengan melakukan berbagai tahapan. Kegiatan yang bertujuan untuk mengembangkan ekonomi kreatif desa ini, dimulai dengan melakukan identifikasi dari potensi desa dan kebutuhan masyarakat, serta perumusan kegiatankegiatan usaha yang dilakukan untuk menjalankan pengembangan ekonomi kreatif ini, yang dimana secara garis besar, program ini terbagi menjadi tiga inti kegiatan, yakni Kegiatan Koordinasi, Kegiatan Pelatihan, Kegiatan Pemasaran. Output yang didapatkan dalam pelaksanaan kegiatan pengabdian ini, berupa dihasilkannya beberapa atraksi wisata di Muara Selayar, berupa atraksi wisata rakit bamboo dan spot photo. Produk wisata yang ditawarkan di Muara Selayar merupakan bentuk kreatifitas Pokdarwis Desa Pijot dengan pembinaan, pengarahan dan pendampingan tim pengabdian Universitas Mataram. Wisata Muara Selayar Desa Pijot diharapkan dapat menjadi salah satu pengembangan mata pencaharian desa, yang bertujuan untuk meningkatkan kesejahteraan dan perekonomian warga Desa Pijot.

\section{Daftar Pustaka}

Aref, F., \& Gill, S.S. (2009). Rural Tourism Development through Rural Cooperatives. Nature and Science. 7(10): 68-73.

Che, D., Veeck, A., \& Veeck, G. (2005). Sustaining production and strengthening the agritourism product: Linkages among Michigan agritourism destinations.

Desbiolles, F.H. (2009). Indigenous Ecotourism role in Transforming Ecological Consciousness. Journal of Ecotourism. 8(2): 144-160.

Hakim L., \& Nakagoshi N. (2008). Planning for NatureBased Tourism In East Java: Recent Status Of Biodiversity, Conservation And Its Implication For Sustainable Tourism. ASEAN Journal on Hospitality and Tourism. 7(2): 155-167.
Kuswiati, W. (2008). A Case Study of Participatory Development in the One Village One Product Movement: Green Tourism in Ajimu Town, Oita, Japan and Agro Tourism in Pasuruan, East Java, Indonesia. Journal of OVOP Policy. 1(11): 6775.

Laverack, G., \& Thangphet, S. (2009). Building Community Capacity for Locally Managed Ecotourism in Northern Thailand. Community Development Journal. 44(2): 172-185.

Zulkarnaen, Reza M. (2016). Pengembangan Potensi Ekonomi Desa Melalui Badan Usaha Milik Desa (Bumdes) Pondok Salam Kabupaten Purwakarta. Jurnal Aplikasi Ipteks untuk Masyarakat. 5 (1): 14. 